Journal of Social Sciences 7 (2): 228-231, 2011

ISSN 1549-3652

(C) 2010 Science Publications

\title{
Economic Growth and Unemployment: An Empirical Analysis
}

\author{
Fuad M. Kreishan \\ Department of Economics, Al-Hussein Bin Talal University, P.O. Box 20 Jordan-Ma’an
}

\begin{abstract}
Problem statement: This research investigates the relationship between unemployment and economic growth in Jordan through the implementation of Okun's law. Approach: Using annual data covering the period 1970-2008, time series techniques are used to test the relation between unemployment and economic growth and to obtain estimates for Okun's coefficient. Namely, the study used Augmented Dickey-Fuller (ADF) for unit root, cointegration test and a simple regression between unemployment rate and economic growth. Results: The empirical results reveal that Okun's law cannot be confirmed for Jordan. Thus, it can be suggested that the lack of economic growth does not explain the unemployment problem in Jordan. Conclusion: The study recommended that economic policies related to demand management would not have an important effect in reducing unemployment rate. Accordingly implementation of economic policies oriented to structural change and reform in the labor market would be more appropriate by policy makers in Jordan.
\end{abstract}

Key words: Empirical analysis, economic growth, Okun's law, Augmented Dickey-Fuller (ADF), Cointegrating Regression Durbin-Watson (CRDW), unemployment rate, structural change, reduction of unemployment, economic policies

\section{INTRODUCTION}

It is a widely accepted view in economics that the growth rate of the GDP of an economy increases employment and reduces unemployment. This theoretical proposition relating output and unemployment is called “Okun's Law”. This relation is among the most famous in macroeconomics theory and has been found to be hold for several countries and regions mainly, in developed countries (Lee, 2000; Farsio and Quade, 2003; Christopoulos, 2004; Daniels and Ejara, 2009). However, there is very few attempts of this kind have been made in developing countries and mainly in Arabs countries. Therefore, the motivation of this study is to test the validity of okun's law for Jordan.

Unemployment with its economic and social implications is one of the most pressing problems facing Jordanian policy makers, high rates of unemployment signal a deficiency in the labor market, deepening poverty incidence and spread indecent standards of living (World Bank, 1994). In Jordan, unemployment rates over the last three decades have been erratic, alternating between periods of very high number of unemployed as in the 1990s, to periods of modest unemployment rate, such as those during 1970s. In fact, unemployment has increased from under an average of $6 \%$ in the 1970 s to over an average of $15 \%$ in the 2000 s (Guegnard, et al., 2005).

Table 1 displays average unemployment and economic growth rates over the last decade, unemployment rate in Jordan fluctuated between 12.5 and $15.3 \%$. Despite a slight decrease in 2007, unemployment rates have been relatively high in comparison with an average growth rate of $6.3 \%$
Table 1: Unemployment rate and economic growth in Jordan (2000-2008)

\begin{tabular}{lll}
\hline Year & Unemployment rate (\%) & Economic growth rate (\%) \\
\hline 2000 & 13.7 & 4.1 \\
2001 & 14.7 & 4.2 \\
2002 & 15.3 & 5.7 \\
2003 & 14.5 & 5.1 \\
2004 & 14.5 & 8.6 \\
005 & 14.8 & 8.1 \\
2006 & 14.0 & 8.0 \\
2007 & 13.1 & 6.6 \\
2008 & 13.5 & 5.4 \\
Average & 14.1 & 6.3 \\
\hline
\end{tabular}

Source: Almanar Database based on EUSs conducted by DOS

during the period 2000-2008, yet Jordan continue to struggle with high an average unemployment rate of $14.1 \%$ during the same period. The predominate feature of unemployment is its high persistence, even during relative boom times. These figures reveal the gravity of the unemployment problem in Jordan. Thus, an investigation of the output relationship will permit analysts to conduct appropriate policies for the reduction of unemployment in the country.

However, despite the social and economic consequences related with high unemployment rates, some additional issues remain unresolved. For example, which factors are responsible for the existence of unemployment? Does the size of unemployment follow an autonomous route independent from other macroeconomic variables?

The answer of these questions is related to the empirical investigation of the relationship between output and unemployment. Given that both variables, that is, economic growth and unemployment rate are affected to a greater or lesser extent by business 
cycle, we would expect a long-run relationship between these variables to exist. Within this context, high rates of output growth will lead to a reduction of unemployment.

In this study, we provide an empirical analysis of the controversial relationship between GDP and unemployment for Jordan.

\section{MATERIALS AND METHODS}

Okun's study remains an important theory. It has been discussed and updated by much economic research this law states that a $1 \%$ reduction in the unemployment rate would reduce approximately $3 \%$ more output. In fact, Okun postulated that a $1 \%$ increase in the growth rate above the trend rate of growth would lead only to $0.3 \%$ in the reduction of unemployment. Reversing the causality a $1 \%$ increase in unemployment will mean roughly more than $3 \%$ loss in GDP growth. This relationship implies that the rate of GDP growth must be equal to its potential growth just to keep the unemployment rate constant. To reduce unemployment, therefore, the rate of GDP growth must be above the growth rate of potential output (Tatom, 1978).

A number of studies have followed investigating empirically the relationship between output and unemployment (Lee, 2000; Viren, 2001; Silverstone and Harris, 2001; Sogner and Stiassny, 2002). These studies mostly revealed the validity of the relation between output and unemployment rate. However, the estimates of Okun's coefficient vary substantially across countries and regions. Moosa studied the validity of Okun's law in four Arab countries: Algeria, Egypt, Moroco and Tunisia. He found that output growth does not translate into employment gains for the four countries, which means that Okun's coefficient turn out to be statistically insignificant.

Keller and Nabil (2002) suggest that economic growth in the MENA rejoin has been insufficient compared to the region's labor force and that high growth does not guarantee good labor market outcomes. On the other hand, the World Bank (2007) suggests that high unemployment is viewed as a reflection of the problems of structural and frictional unemployment in MENA countries. It seems that the World Bank Report suggested that Okun's coefficient is low or insignificant among MENA countries.

Data sources: the data for the study was obtained from a combination of various sources as the following:

- Central Bank of Jordan annual reports

- Department of Statisticics (DOS)
- The Jordanian labor force database: Royal scientific society

Model description: Using the knowledge gained from the surveyed literature, the study used a standard version of Okun's law, which is given as follow:

$$
\mathrm{y}_{\mathrm{t}}=\beta_{\mathrm{o}}+\beta_{1} \mathrm{u}+\mathrm{e}_{\mathrm{t}} \ldots
$$

Where:

$\mathrm{y}=$ The real output product

$\mathrm{u}=$ The level of unemployment

$\mathrm{e}=$ The white-noise disturbance term

In Eq. 1 the parameter (B) is known as the Okun coefficient and indicates changes in real output caused by changes in unemployment rate. The estimated elasticity provides a measure of the relationship between employment and economic growth; where low estimates of Okun's coefficient suggest little correlation between economic growth and employment rate, while high estimates of the slope coefficient provides support of Okun's law.

\section{RESULTS}

In order to obtain reliable regression results, we first need to make sure that our model could not be subject to "spurious regression" (Gujarati, 1995) therefore, we first test the nature of the time series to determine whether they are stationary or non stationary and also their order of integration perform unit root test on the time series macro-variables in our sample. First, the Dickey-Fuller test was applied to both variables to detect if these variables were stationary or non-stationary. Both variables proved to be non-stationary; therefore, our regression tests were applied to the first differences. The results are obtained in Table 2.

The cointegration properties of the principal series are investigated. The following contegrating equations were used.

$\ln \mathrm{GDP}_{\mathrm{t}}=\alpha_{\mathrm{o}}+\alpha_{1} \ln \mathrm{u}_{\mathrm{t}}+\mathrm{e}_{\mathrm{t}} \cdots$

$\ln \mathrm{u}_{\mathrm{t}}=\lambda_{\mathrm{o}}+\lambda_{1} \ln \mathrm{GDP}_{\mathrm{t}}+\mathrm{e}_{\mathrm{t}} \cdots$

If the log of (GDP) growth rate and (u) rate cointegrated, then the residuals from the cointegration Eq. 2 and 3 must be integrated to order zero, meaning that the residuals are stationary. To ascertain whether the null hypothesis of no cointegration is rejected the Cointegrating Regression Durbin-Watson (CRDW) 
Table 2: ADF unit root test

\begin{tabular}{lll}
\hline Variable & levels & Differences \\
\hline Log real GDP growth rate & -2.10 & -4.54 \\
Log unemployment rate & -2.42 & -6.79 \\
\hline
\end{tabular}

Source: Author's calculations

Table 3: Cointegration test

\begin{tabular}{llll}
\hline Equation & Slop & CRDW & ADF \\
\hline 1 & 1.01 & 2.85 & -4.23 \\
2 & 1.79 & 2.54 & -4.12 \\
\hline Source:
\end{tabular}

Table 4: Simple regression

\begin{tabular}{lllllll}
\hline Dep. Var. & Indep.Var & Coffi & Coff. t-stat. & F & $\mathrm{R}^{2}$ & DW \\
\hline Dlu & Dlg & -0.30 & -2.30 & 5.312 & 12.5 & 1.8
\end{tabular}

Sample: 1970-2008; Dlu (u): First differences of logarithm of unemployment rate. Dlg (GDP): First differences of logarithm of GDP

statistic from the ordinary last squares estimation of Equations 2 and 3 are used. The CRDW statistic indicates that it is significantly different from zero and larger than the CRDW critical value of 0.89 at the 5\% level (Engle and Yoo, 1987). However, another formal test is the ADF test on the residuals of Equation 2 and 3 is used. The results of ADF test statistics are (-4.23) and (-4.12), Table 3. On the basis of Mackinnon (1991) critical values, cointegration is supported.

Finally, having established that real GDP is related thus a long-run equilibrium relationship exists between these variables, thus we proceed to estimate Eq.1. Both variables proved to be non-stationary; therefore, the regression tests were applied to the first differences of logarithms for both variables. Table 4 displays the regression test results. Despite, the negative sing of the slope coefficient implies a negative relation between the two variables, the absolute value of the t-statistic for the slope coefficient (-0.3) is not significant at any confidence level. Moreover, the calculated adjusted R-squared and the F-statistic does not confirm the strong relationship between the two variables. This provides support for that unemployment does not depend on economic growth. Therefore, based on our findings, we believe that Okun's law does not hold for Jordan.

The absence of a statistically significant relation between unemployment and output at the aggregate level indicates that a cyclical recovery will not be accompanied by reduction of unemployment. Furthermore, this might reflect the sizable structural and/or frictional component of unemployment in Jordan. In fact, this has mostly been the case in most Arab countries and other developing countries (Moosa, 2008).

\section{DISCUSSION}

The explanation for this result is that unemployment in Jordan like other Arab countries is structural but not cyclical. Structural unemployment results from unemployed people who do not have the skills and qualifications to do the available Jobs. In this case, economic growth cannot reduce these kinds of unemployment. On the other hand, despite Jordan has implemented an ambitious program of economic reform since 1989 with the support of the IMF and the World Bank, to restructure the economy with an aim of boosting economic growth and enhancing the role of the private sector in the economy mainly in employment. The labor market in Jordan is still dominated by the government as the prime source of demand for labor (Guegnard, et al., 2005).

In recent study by the World Bank (Razzaz and Iqbal, 2008) staff suggested that the link between growth and unemployment in Jordan is affected by the types of jobs that are created mainly (manual jobs), by the incentives employers have to choose between foreign and local workers and by the choices that nationals make between accepting a local job and staying voluntarily unemployed in search of a better job overseas or in the public sector. They explained that despite Jordan achieved strong GDP growth and created many new jobs. However, unemployment (among nationals) did not decline but fluctuated around a fairly high level of $14 \%$, the bulk of new jobs created have been taken by foreign workers. This is because; domestic workers have relatively high reservation wages, based on expectations of obtaining public sector or foreign jobs and of income support from families. More than $50 \%$ of the unemployed indicate that they are unwilling to take available jobs at prevailing wages.

From what have been discussed we can conclude that unemployment problem in Jordan reflect the behavioral nature of unemployment in Jordan, thus to reduce unemployment rates, much hope lies in reform acceleration for the labor market regulation in Jordan: Efforts like continuous improvements to working conditions and higher salaries will eventually convince Jordanians to accept manual and then reduce unemployment rates in the long-run.

\section{CONCLUSION}

This study attempts to provide an empirical analysis of the relationship between GDP and unemployment for Jordan during the period (19702008) using for this purpose time series techniques. Fourth more, the study provided an estimation of Okun's coefficient. Our empirical analysis consisted of Dickey-Fuller test, cointegration test and a simple regression between unemployment rate and economic growth. The results presented in this study, showed that the data series are stationary in their differences. Tests of cointegration revealed long-run association between unemployment and economic growth. 
On the other hand, the results support that unemployment and output are unrelated. Therefore, our findings suggest that Okun's law is not valid for Jordan. It can be suggested that the lack of growth does not explain the unemployment problem in Jordan. Thus, our results have an important policy implication, the economic policies related to demand management would not have an important effect in reducing unemployment in Jordan however, economic policies more oriented to structural changes and reform in labor market would be more appropriate in the case of Jordan. Finally, the results of this study come in line with other study in the Arab countries.

\section{REFERENCES}

Christopoulos, D., 2004. The relationship between output and unemployment: Evidence from Greek Regions. Stud. Regional Sci., 83: 611-620. DOI: 10.1007/s10110-004-0198-y

Daniels, K. and D.D. Ejara, 2009. Impact of information asymmetry on municipal bond yields: An empirical analysis. Am. J. Econ. Bus. Admin., 1 : 11-20. DOI: 10.3844/ajebasp.2009.11.20

Engle, F.R. and B.S. Yoo, 1987. Forecasting and testing in co-integrated systems. J. Econ., 35: 143-59. DOI: 10.1016/0304-4076(87)90085-6

Farsio, F. and S. Quade, 2003. An empirical analysis of the relationship between GDP and unemployment. Humanomics, 19: 1-6. DOI: 10.1108/eb018884

Guegnard, C., X. Matheu and M. Shteiwi, 2005. Unemployment in Jordan. 1st Edn., Office for Official Publications of the European Communities, Luxembourg, ISBN: 9291574538, pp: 65.

Gujarati, D., 1995. Basic Econometrics. 3rd Edn., McGraw-Hill, USA., ISBN: 9757860557, pp: 838.

Keller, J. and M.K. Nabil, 2002. The Macroeconomics of Labor Market Outcomes in MENA over the 1990s: How Growth has failed to keep Pace with a Burgeoning Lab our Market, Working Study, The Egyptian Center for Economic Studies. http://siteresources.worldbank.org/INTMENA/R esources/Labmarkoutcomes.pdf
Lee, J., 2000, The Robustness of Okun's law: Evidence from OECD countries. J. Macroecon., 22: 331-356. DOI: 10.1016/S01640704(00)00135

Mackinnon, J., 1991. Critical Values for Cointegration Tests. In: Long-Run Equilibrium Relationships: Readings in Cointegration, Engle, R.F. and C.W.J. Granger (Eds.). Oxford University Press, USA., ISBN: 0198283393, pp: 267-276.

Moosa, I., 2008. Economic growth and unemployment in Arab countries: Is Okun's law Valid? Proceedings of the International Conference on the Unemployment Crisis in the Arab Countries. Mar. 17-18, Cairo- Egypt, pp: 1-19.

Razzaz, S. and F. Iqbal, 2008. Job Growth without Unemployment Reduction: The experience of Jordan. The World Bank. http://www.iza.org/conference_files/worldb2008/ razzaz_s4349.pdf

Silverstone, B. and R. Harris, 2001. Testing for asymmetry in Okun's law: A cross-country comparison. Econ. Bull., 5: 1-13.

Sogner, L. and A. Stiassny, 2002. An analysis on the structural stability of okun's law--A cross-country study. Applied Econ. Lett., 34: 1775-1787. DOI: 10.1080/00036840210124180

Tatom, J.A., 1978. Economic Growth and Unemployment: A Reappraisal of the Conventional View, Federal Reserve Bank of St. Louis. pp: 16-23.

Viren, M., 2001. The Okun curve is non-linear. Econ. Lett., 70: 253-257. DOI: 10.1016/S01651765(00)00370-0

World Bank, 1994. The Hashemite Kingdom of Jordan Poverty Assessment. Country economic and sector reports. http://blds.ids.ac.uk/cf/opaccf/detailed.cfm?RN= 136601

World Bank, 2007. MENA Economic Developments and Prospect: Job Creation in an Era of High Growth, Washington DC, pp: 1-11. http://siteresources.worldbank.org/INTMENA/R esources/EDP07_SUMMARY_APRIL12.pdf 